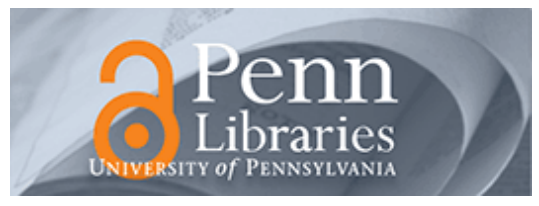

University of Pennsylvania ScholarlyCommons

\title{
Life as a Chord: Heterogeneous Resources in the Social Identification of One Migrant Girl
}

Stanton Wortham

University of Pennsylvania, stanton.wortham@bc.edu

Catherine R. Rhodes

University of Pennsylvania, rhodesc@gse.upenn.edu

Follow this and additional works at: https://repository.upenn.edu/gse_pubs

Part of the Anthropological Linguistics and Sociolinguistics Commons, and the Bilingual, Multilingual, and Multicultural Education Commons

\section{Recommended Citation}

Wortham, S., \& Rhodes, C. R. (2013). Life as a Chord: Heterogeneous Resources in the Social Identification of One Migrant Girl. Oxford University Press, 34 (5), 536-553. http://dx.doi.org/10.1093/ applin/amt021

This article appears in: Special Issue: Transnational Identities

This paper is posted at ScholarlyCommons. https://repository.upenn.edu/gse_pubs/249

For more information, please contact repository@pobox.upenn.edu. 


\title{
Life as a Chord: Heterogeneous Resources in the Social Identification of One Migrant Girl
}

\author{
Abstract \\ The social and natural worlds provide heterogeneous resources that contribute both to instances of \\ social identification and to life trajectories. One might claim or be assigned membership in various \\ groups, which emerge at different spatial and temporal scales, and resources for social identification are \\ often combined in novel ways to yield unexpected identities. To account for the trajectories of \\ identification that any individual travels, analysts must determine which configurations of resources \\ become relevant in a given case. Of the many resources that might be relevant to identifying an individual, \\ event, or setting, a few generally become salient-somewhat like several musical notes coming together \\ to constitute a chord. We illustrate this contingent process by describing one young Mexican migrant in \\ the USA, sketching relevant aspects of family interactions, educational practices, local community \\ characteristics, and national discourses. This girl, her family, and other actors combine heterogeneous \\ resources in contingent ways as they navigate and establish an emerging trajectory of identification \\ through which she becomes a 'good reader'.
}

\section{Keywords}

Migrant, literacy, resources, spatial and temporal scales, Mexican migrant girl

\section{Disciplines}

Anthropological Linguistics and Sociolinguistics | Bilingual, Multilingual, and Multicultural Education | Education

\section{Comments}

This article appears in: Special Issue: Transnational Identities 


\title{
Life as a Chord: Heterogeneous Resources in the Social Identification of One Migrant Girl
}

\author{
*STANTON WORTHAM and CATHERINE RHODES \\ University of Pennsylvania, PA, USA \\ *E-mail: stantonw@gse.upenn.edu
}

\begin{abstract}
The social and natural worlds provide heterogeneous resources that contribute both to instances of social identification and to life trajectories. One might claim or be assigned membership in various groups, which emerge at different spatial and temporal scales, and resources for social identification are often combined in novel ways to yield unexpected identities. To account for the trajectories of identification that any individual travels, analysts must determine which configurations of resources become relevant in a given case. Of the many resources that might be relevant to identifying an individual, event, or setting, a few generally become salient-somewhat like several musical notes coming together to constitute a chord. We illustrate this contingent process by describing one young Mexican migrant in the USA, sketching relevant aspects of family interactions, educational practices, local community characteristics, and national discourses. This girl, her family, and other actors combine heterogeneous resources in contingent ways as they navigate and establish an emerging trajectory of identification through which she becomes a 'good reader'.
\end{abstract}

\section{INTRODUCTION}

One day 8-year-old Allie bought a book. Allie spent that afternoon with her mother, her two younger siblings, and two researchers. By the time Allie's father Herná $\mathrm{n}$ arrived home from work, Allie had read about half of the book. After Allie's mother left for her job, Rhodes described the activities of the day to Herná n. He sat with the researchers and Allie at the kitchen table while he cared for his two younger children. When the researcher told Herná $\mathbf{n}$ about Allie's remarkable progress reading her new book, he replied, ‘¡ ¿sí?!'. Allie immediately answered, ‘ $¡$ sí!'. Herná n then contrasted reading practices in the USA and Mexico:

¿Ahora? Yo no sé, bueno, en México no ... se acostumbra mucho a leer. En México, es muy raro él que, que ... se pone a leer.... Y, este, aquí veo que ... la mayoría leen, y leen, y leen .... Por eso, me imagino que por eso es un país má s ... má s avanzado.... Más avanzado, no, no sé a que se deba, ... pero ... En México es... muy raro que alguien lea...' 
And now? I don't know, well, in Mexico ... people aren't much accustomed to reading. In Mexico, it's a very unusual person who, who... puts him/ herself to (just starts) reading.... And, um, here I see that ... the majority (of people), they read, and read, and read... . Because of this, I imagine that, because of this, it's a country that is more... more advanced. More advanced, I don't, don't know what it is due to,... but... In Mexico, it's... very unusual for someone to read...

At the same exact moment that Allie's father said, 'in Mexico, it is a very unusual' for someone to just start reading, Allie began to read aloud, in English, from her new book. Her father continued to speak with the researchers, explaining how unusual it would be for someone in Mexico to read spontaneously and speculating that the USA might be more advanced because Americans read. Throughout this entire exchange, Allie continued to read quietly in English - audibly, but not disturbing anyone. She stopped periodically to respond to back-channel requests from her younger siblings, although she sighed loudly when they interrupted her.

By reading during her father's comments on differential national literacy, Allie unwittingly positions herself as a young person who reads, in English, something that her father says does not happen in Mexico. Allie loves and respects her father, and she is proud to be Mexican. But she is unlike her father in important ways - she speaks and reads English, she reads spontaneously for fun, and she likes school-and thus her life trajectory will be different from his. Like many migrants in transnational situations, she encounters various ways of engaging others and understanding herself, and she has available various resources for identifying herself as she becomes a student, a reader, and a daughter. How can we account for her actual life trajectory and emerging identities, given the various resources that are potentially relevant to the trajectories that she could follow? This is a concrete question about Allie's life, but it is also a theoretical question about how we explain emerging trajectories of identification among the heterogeneity of possible pathways available in the contemporary world. How do we know which of the various potentially relevant resources contribute to Allie's emerging identity as a good reader?

In this article, we draw on Silverstein (1992, 1993), Agha (2007), and Latour (2005) to answer this question. When offering an account of any given social process or phenomenon, some aspects of context become relevant and other potentially relevant ones do not. This can be compared with playing a chord, where many musical notes are available but only a few actually compose the chord. The individual notes are like potentially relevant resources-models, objects, and habitual stances-some of which are brought together to help constitute a trajectory of social identification for someone like Allie. We use this chord metaphor to clarify how the general theories developed by Silverstein, Agha, and Latour address the problem of selecting relevant resources.

A musical chord is any harmonic set of three or more notes (Károlyi 1965). Chords in a sequence are known as a chord or harmonic progression. A chord 
progression 'aims for a definite goal' of establishing or contradicting a tonality founded on a root or tonic chord (Schoenberg 1983). Harmony in music involves relations among chords. We use chords and chord progressions as an analogy for instances and trajectories of social identification. In accounting for any focal object or process, like the social identification of Allie as a good reader, many resources could be relevant. Does her gender matter? Does the emergence of English as a world language matter? Does her location in an area of non-traditional Latino settlement matter? Does her position as the oldest child in her family matter? In any given case, a small subset of potentially relevant resources comes harmoniously together to facilitate the focal process or phenomenon. The relations among chords in a larger piece of music are like the cross-context patterns that facilitate broader processes like trajectories of social identification. Resources that become relevant across events combine to help establish an emerging social identity, as chords combine into a piece of music. This article develops the chord metaphor and applies it to Allie's emerging social identity.

\section{Networks of relevant context}

Working in the field of linguistic anthropology, Silverstein (1992, 1993) provides a sophisticated account of how relevant context emerges so that a speech event and its constituent utterances come to have meaning. He explains how key utterances in an interaction come to have definite functions, and how the overall event comes to be identifiable as some recognizable type, as indexical signs point to relevant aspects of the context. In the segment above, for example, the word 'avanzado' (advanced) indexes a set of ideologies about more and less 'educated', 'developed' and even 'civilized' societies. By using this word, Herná $\mathrm{n}$ makes available an inference about relative status between himself and the researchers (and perhaps his daughter). Silverstein shows how one sign like this does not in itself necessarily make that context relevant to understanding an event. Only when subsequent indexical signs come to presuppose the same context does it become relevant. Silverstein calls this a 'poetic structure', a set of co-textual indexical signs that point to and reinforce each other's salience and which collectively establish certain aspects of context as relevant. Other potentially relevant signs (and the contexts they might have indexed) fade into the background as subsequent signs do not presuppose them. Thus, Silverstein describes a dialectic between an emerging conception of what is happening in the event as a whole and construals of particular signs and utterances.

Agha (2007), Agha and Wortham (2005), and Wortham (2006) extend this account beyond the speech event, describing how chains of events come to cohere across hours, days, or years. Many phenomena involving the social functions of language take shape across and not merely within events-as an individual comes to be identified ontogenetically, a way of speaking gets established and characterized sociohistorically, and so forth. Silverstein's 
account can be extended beyond a discrete event, as indexical signs across more than one event come to presuppose each other and relevant contexts, thus making possible inferences about individuals or groups. But the result occurs at a different scale than event-level processes (temporally, and often spatially). Within one event, poetically organized co-textual signs cohere, establish relevant context and allow participants to interpret what is happening. For example, in the kitchen conversation introduced earlier in the text, perhaps Herná $\mathrm{n}$ is positioning Allie on the side of the researchers, as likely to enter their world of American professionals. Similarly, across a series of events, poetically organized signs cohere and establish relevant context that allows participants to enact or interpret a solidifying trajectory-perhaps a trajectory of identification, in which someone like Allie comes to be identifiable in a given social position. Allie does many things besides interact with her family. She also participates in school-based events involving English literacy-like the Reading Olympics. Across contexts, her identity as a good reader and a particular type of migrant emerges and solidifies.

Moving beyond speech events to examine cross-event trajectories helps us move beyond the pervasive but misleading 'macro-micro dialectic'. On a 'macro-micro' account, Allie's positioning in the interaction with her father would both constitute and be constituted by more enduring categories and processes: e.g. Mexicans would be stereotyped in certain ways, the state would have certain institutional procedures that migrants cannot avoid, and such 'macro' facts would constrain how Allie and her father act. At the same time, individuals could 'agentively' work against such constraints by violating or modifying them in particular interactions. It has become clear in recent years that such a 'macro-micro' approach cannot suffice. Wortham (2006, 2012) and Wortham and Rhodes (2012) develop this argument, showing that 'macro-micro' accounts misconstrue heterogeneous resources from various scales, forcing them into two artificially bounded scales instead of exploring how a subset of resources from various scales become relevant to social identification in any given case. We are not arguing that 'structure' and 'agency' do not exist. Instead of one monolithic type of structure, however, there are various types of constraining processes that occur at various scales - ranging from evanescent local ones to enduring long-term ones. On the other side, innovation occurs not only because of individual acts of will but can also emerge from collective processes at various scales (Wortham 2012).

In this article, we take Allie's development as our focal phenomenon - an emerging solidifying set of identities that she enacts over her later elementary school years in the USA. She is becoming a 'good reader', and Allie, her parents, her teachers, and others now often identify her this way. She fluidly enacts a set of embodied skills and relational positions appropriate to this identity. This focal phenomenon is not one event or a stable set of traits or external categories. It is a heterogeneous amalgam of ideas, embodied dispositions, and material objects that emerges across events for several years. 
Our question is how do we explain which potentially relevant ideas, dispositions, and objects become relevant to and make possible this focal process?

We offer the chord metaphor as a heuristic for envisioning this complex process. The metaphor has two components: one describing discrete events of identification and the other describing trajectories across linked events. In any event of social identification, like the conversation in Allie's kitchen, several resources from various scales will be relevant to explaining how a particular social identity emerged for her. These resources are like the notes of a chord, harmoniously coming together to facilitate the event of social identification. There are also many other events in which Allie's identity as a reader is established-like those at school involving Allie and educators, others at special events with peers and parents, and so forth. These events together form a trajectory across which Allie's identity emerges. Each event presupposes a set of relevant contexts and resources, like the notes composing a chord, and the trajectory is like a chord progression in which related chords are played in sequence and form a larger whole. In any given case, the chords and chord progressions may be familiar and enduring, like the chords that compose a recognizable genre of music, or they can be relatively unique like an improvised performance.

Many resources are potentially relevant to Allie's case. For example, during a timescale of two centuries, Mexico and the USA have developed a complex hierarchical relationship, which has led to migration policies and economic conditions that lead some Mexicans to risk traveling without documents, and this has yielded stereotypes of Mexicans as less likely to succeed (Wortham et al. 2009). During a timescale of two decades, recent Mexican migration to areas of the USA that have not traditionally been home to Latinos has yielded more flexibility for migrants because longstanding residents unfamiliar with Latinos less often apply entrenched stereotypes and thus sometimes give immigrants more space for self-definition (Wortham et al. 2002; Hamann and Harklau 2010; 80\% of the Latinos in our research site are Mexican, and we use both 'Latino' and 'Mexican' to refer to them). The town where Allie lives has a distinctive history of immigration such that it is more welcoming toward immigrants than many others. During a timescale of one decade, Allie's family has developed its own history of migration, and Allie's ontogenetic trajectory differs from that of many children in similar circumstances. It is relatively easy to imagine how these foregoing resources or processes might be relevant to the emergence of Allie's identity as a reader. But many other potentially relevant resources exist. For example, Spanish and English differ in their grammatical encoding of motion (Talmy 1985). Given that Allie speaks English and Spanish, this might be relevant-but it does not seem to account for important aspects of her social identification in the same way as the previous ones. How do we rule out such potentially relevant resources, determining that they do not contribute to a focal process or phenomenon? 
Silverstein and Agha offer a general answer to this question, in terms of signs that collectively presuppose relevant context across events. People mobilize heterogeneous resources from various scales by deploying signs that point to relevant context and help constitute some focal object or process. Latour (2005) complements this account in useful ways. He argues that the social world is constructed out of heterogeneous 'assemblages'. For any focal phenomenon, a 'network' has been constructed, and this network is heterogeneous in both scale and type. Ideas, objects, and dispositions from different scales are brought together (Lemke 2000). In Allie's case, as illustrated later in the text, it matters that she grows up in a town of the New Latino Diaspora (NLD) (Wortham et al. 2002; Hamann and Harklau 2010), where stances toward Latino migrants are less entrenched than in areas of traditional Latino settlement. It also matters that she is Mexican and not some other nationality because of the history of Mexican migrants in the USA during the past century and associated models of Mexicanness. These two patterns, as well as others described later in the text, form part of the network of heterogeneous resources relevant to constituting Allie's emerging identity, despite the fact that they have themselves emerged over different spatial and temporal scales (the NLD during the past 20 years and models of Mexicanness in the USA during at least two centuries). A network is also heterogeneous in type. Material objects matter, like the spatial and educational segregation of residents in Allie's town and the resources like books available to children from different groups. Ideas matter, like the models of personhood circulated in the media that represent Mexicans in certain ways. And embodied dispositions matter, like the pleasure Allie takes in reading a book and her facility in conversations about text.

In Allie's case, we will argue that these particular resources are relevant to her identification as a good reader, while many other potentially relevant ones (e.g. facts about English and Spanish verbs) are not. Latour argues that no particular process, scale, or resource is always relevant. Even though the NLD and the flexibility offered there is important to Allie, this particular context or resource will not be important to every Mexican student in Allie's town. Some of her peers travel trajectories similar to those established by Latino children in areas of traditional Latino settlement. Social analysts should not 'limit in advance the shape, size, heterogeneity, and combination of associations' in the network (Latour 2005: 11). We must account for how, in a given case, a heterogeneous group of resources is assembled in a contingent way and becomes the relevant network to account for a focal process. In our metaphor, this is like the harmonious co-occurrence of notes that compose a chord and the harmonious progression of chords across a piece-while setting aside the other possible notes (resources) that might have been played but were not relevant. Our job as analysts is to describe the network of resources that become relevant to a focal case or class of cases. 


\section{Marshall and the NLD}

We have been conducting ethnographic and sociolinguistic research with multiple families, across multiple institutions, for $>7$ years in one Mid-Atlantic suburb that we call Marshall. Data include almost 1,000 fieldnotes, interviews, and videotaped interactions in schools, churches, community institutions, businesses, and individuals' homes. Researchers have spent the past 3 years collecting data with Allie and her family in Marshall. We have spent time with Allie and her family on >50 occasions - at home, in church, on family trips, and at academic events in and out of school. We have over a dozen hours of video footage with Allie and her family, and they are central characters in a documentary we have completed. Our ethnographic analyses follow Emerson et al. (1995) and Maxwell (1996), iteratively drawing patterns out of fieldnotes, documents, transcribed interviews, and videotaped classes.

Following Murillo (2002) and Villenas (2002), we describe Marshall as an NLD community, a place that has not historically been home to Latinos but which has recently experienced rapid Latino migration. In the past 15 years, longstanding patterns of Mexican presence in the USA have changed, with large numbers of Mexican immigrants settling in the Midwest, the South, and the Northeast - often in rural and suburban areas where Mexican-origin people have not lived before-resulting in growth of the Latino population as high as $300 \%$ or more (Suro and Singer 2002). The bulk of this growth is among Mexicans. The Mexican-origin population in Marshall has increased 900\% between 1990 and 2010 (compared with a 54\% increase in the Mexican population nationwide). Latinos now represent almost a third of Marshall's total population (going from 2 to $28 \%$ over the 20 -year period; US Census Bureau 2011).

The growth of Marshall's Mexican community did not mirror the broader trend in the USA that De Fina (2003) describes, in which many communities started with single, male, Mexican immigrants (solteros) who migrated without their families. These men would work in the USA, travel back and forth to Mexico, and send money home. Marshall did experience a stage in which many solteros arrived on their own or with fragments of families in the late 1990s, but this stage was preceded by early arrivals through one family network. Part of what drew Mexicans to Marshall can be traced to a single Mexican immigrant who arrived in the late 1970s. She and seven of her siblings are now professionals or small business owners, and they serve as cultural brokers who help more recent Mexican immigrants by connecting them to information about employment, housing, and social services. This family has been instrumental in Marshall's Latino community, as migrants with social capital who offer important support for newcomers.

About 20 years after Martha's arrival, a wave of solteros and migrant workers arrived in Marshall. Among them was Allie's father, who arrived in 2003. He came to the USA with a common goal: saving enough money to improve his family's life in Mexico and then returning. In the past 10 years, however, in 
Marshall and elsewhere, Mexican migration patters have changed (Suro and Singer 2002; Pew Hispanic Center 2011). There are fewer single men and more families, especially young families with children. Because of stricter border enforcement, it is no longer practical to go back and forth and many Mexican families have settled more permanently in places like Marshall (Massey and Sánchez 2010; Pew Hispanic Center 2011). This has generated more Latino births and increasing Latino school enrollment (27\% of students in Marshall schools were Latino in 2012, and "-50\% of kindergarteners). Herná $\mathrm{n}$ and his family represent this trend toward more settled Mexican migrant communities. His wife and Allie joined him in 2004, and in 2006 Allie began kindergarten. Her siblings were born shortly thereafter. The family has always intended to return to Mexico, but their return date has repeatedly been pushed back as new expenses and plans arise.

The Pew Hispanic Center (2011) has documented how the number of new immigrant arrivals from Mexico to the USA has fallen steeply in recent yearswith a 60\% reduction between 2006 and 2010. The number of Mexicans returning to Mexico from the USA has declined as well-a $33 \%$ reduction over that same period (Pew Hispanic Center 2011). This reduction in return migration may be due to the increased financial costs and the increased danger of crossing the border. The shift from solteros to Mexican families complicates border crossing, as it is harder to cross with children. In Marshall, what used to be a community of Mexican migrants is now mostly a community of families that have settled more permanently, established businesses, become members of churches and brought family members there.

In part, because Marshall's Latino community is relatively new, longstanding residents have more fluid views about Mexicans than one finds in national discourse and in areas of traditional Latino settlement (Millard et al. 2004; Gouveia et al. 2005). For example, both whites and Mexicans in Marshall compare Mexican migrants with Italians and other local groups who are seen as assets to the community. In this respect, Mexican migrants are seen as model minorities: hard working, uncomplaining people whose work and faith are rejuvenating the town as they pursue the American Dream (Wortham et al. 2009). Italian Americans are often more sympathetic to Mexican immigrants than other residents because they remember their own immigrant roots, because most belong to the Catholic church, and because they perceive Mexicans to have a similar language and similar emphasis on family. We have argued elsewhere that this more positive set of possible identities for Mexican migrants makes Marshall more welcoming and provides a wider range of roles that Mexicans can adopt (Wortham et al. 2009).

\section{Heterogeneous resources in Allie's social identification}

Allie has just finished her first year of middle school in Marshall. We cannot know her full life trajectory. But we can sketch various resources that have become relevant to her emerging identities as a successful student, a good 
reader, and a Mexican migrant. We have already introduced some of the heterogeneous resources that have become part of the network shaping Allie's trajectory: the hierarchical positioning of the USA and Mexico as geopolitical entities, established through material differentiation and cultural stereotypes; Marshall's distinct local immigration history, both as a NLD town and as a town whose residents remember their own immigrant roots; local institutional discourses about education, bilingualism, and literacy; and ontogenetic processes through which Allie and her family are developing. In this section, we sketch important resources that inform Allie's trajectory of identification, leading up to the interaction in her kitchen that we introduced earlier in the text.

Allie's parents met as teenagers in Puebla, Mexico. Allie and her mother came to the USA and spent a year with relatives in Chicago and New York before joining Herná $\mathrm{n}$ in Marshall. Allie was two when she came to the USA and three when the family was reunited. The following year she began kindergarten. Allie's first language was Spanish, as her parents are monolingual Spanish speakers. When Allie started school, she was placed in the English as a Second Language (ESL) program, and she remained in that program for 5 years-despite the fact that her oral and written English quickly surpassed her Spanish. By the middle of elementary school, Allie was much more comfortable reading and speaking English. Allie speaks English at school and speaks Spanish outside of school, except occasionally when she interacts with Anglos in town. Her parents mostly visit businesses where Spanish is spoken, and her neighbors also speak Spanish, but her command of English is much broader than her command of Spanish. Her parents say that she forgets words in Spanish that she knows in English, and that she knows more words in English than in Spanish. Allie's Spanish has also become inflected with English syntax and phrasings.

When researchers arrive at her home, Allie immediately switches to English-despite the fact that the research team members speak Spanish well and the fact that her parents cannot participate in English conversations. Allie does not want to exclude her parents. It just seems easier for her to speak English, and she often struggles to find appropriate words in Spanish. When Allie is playing on her own at home, she also talks to herself in English. One day, "-2 years ago, her parents and two researchers were playing outside of their home in the snow. One of the researchers was recording an interview with Allie's mother in Spanish while the children played. Allie was playing alone in the snow nearby. She made snowballs and snow angels, and throughout spoke quietly to herself in English: 'Got it!' 'Oh, now I know what I can do!' At one point her mother said, 'No, Allie', worried that she might fall. Allie immediately responded, 'Huh? ... ¿Qué ?'-quickly correcting herself by repeating the question in Spanish.

Although Allie is more comfortable in English, she can function well in Spanish, and she does read and write Spanish, although she has fewer opportunities to practice Spanish literacy. Her shift to English comes from living in 
an English-dominated country with an institutionalized aversion to bilingualism. Many have shown how 'U.S. bilingual policy ... aims not to produce bilinguals but to promote linguistic assimilation and ameliorate presumed deficits ('limited English proficiency') in children learning English as a second language' (Ruiz 1988). Rosa (2010) describes a typical high school where students were encouraged to abandon Spanish and become monolingual English speakers. Members of our research team have found similar attitudes about bilingualism as a deficit in Marshall, and these may be pushing Allie away from Spanish, although we have found some pro-bilingualism ideologies in Marshall as well (Gallo et al. in press). These larger ideologies have implications for Allie's relations with her parents and her emerging sense of self.

Thus, one relevant aspect of the context - a resource that contributes to Allie's identification as a student, a reader, and a migrant - is the familiar American emphasis on monolingualism and deficit models of those who do not speak English, especially as these are institutionalized in schools. This resource, this note in the chords that metaphorically constitute Allie's trajectory of identification, would be the same for migrant students in most of the USA. But other relevant resources are particular to Allie's location in a somewhat-unique town at one historical moment. Using our metaphor, the chord or harmonious collection of resources in Allie's cases is not particularly familiar, despite the fact that it has familiar notes in it. Allie arrived in Marshall as part of a surge in Latino school enrollment in this town. If she had arrived as a kindergartener 10 years earlier, she would have been treated differently, and if she had arrived as an adolescent, she would have been differently placed with respect to the school's demands and her language abilities. Many Latino immigrant families in Marshall started settling and having children "-10 years ago, and thus Allie began school right as the first sizable generation of Latino kindergarteners was enrolling. These students were different from the smaller number of migrant Latino students who had attended Marshall school previously because the larger population of Mexican schools children contributed to a somewhat different ideology about language than the one just described.

At the elementary school level, teachers and students in Marshall now often positively evaluate Spanish. We have observed non-Spanish-speaking students use basic Spanish words and phrases, and even invent "faux Spanish" by using Spanish-sounding phonology with nonsense syllables, thus claiming to speak Spanish when they do not (Gallo et al. in press). For Allie, then, there is some support for maintaining bilingualism-supportive attitudes and models of Spanish speakers for her to enact-because of her arrival at a particular historical moment and at a particular point in her ontogenetic trajectory. Despite becoming English-dominant, Allie uses Spanish in public when appropriate and, at a teacher's urging, she has become literate in Spanish.

Allie's parents can read Spanish, but they do not do so very often. They do not read with their children. Although they do worry about Allie losing her Spanish, her parents do not see English as a problem. They use her as a 
resource when negotiating in public with English speakers, as Orellana (2009) describes with many migrant children. They also ask her to read written material in English. Thus, they encourage her positioning as a successful reader of English.

Allie's identity as a good reader is emerging alongside her identification with Mexico. She reminisces about Mexico and her grandparents, whom she writes to in Spanish. She also created check-box-style quizzes when Rhodes was traveling to Mexico, asking the researcher to pick which country she preferred-Mexico or the USA. Allie said she hoped the researcher would pick Mexico. Although Allie's parents do not romanticize Mexico, they frequently talk about what they miss and their plans to return. Yet, they also appreciate what the USA offers, including access to goods, services, and jobs. Having their two youngest children delivered in a hospital is one of the things Allie's mother particularly appreciates. Allie's parents acknowledge that she is getting a good education in the USA and that being bilingual will be an advantage.

Marshall is different now from when Allie arrived. Today, along with the much larger numbers of Latino students, the school district has significant bilingual staff. When Allie's younger siblings start school, the situation will again be different. Allie had to figure things out for herself in school. Her parents had limited experience with the Mexican educational system and no experience in the USA. They could not help her with homework or talk to her teachers without an interpreter. Allie was placed in ESL classes that provided her with extra attention, and she took advantage of summer classes that the district offered to provide academic support for ESL students. Allie was mentored into her school's reading club and Reading Olympics team by a supportive teacher, and these activities have facilitated her development as a reader. When Allie's siblings start school, they will have Allie to guide them. The demographics will be different by then, however. Allie's siblings may be part of the majority in school, and they may not receive some of the resources that were available to Allie. Perhaps they will not need them, but it is also possible that they will be overlooked.

In making sense of Allie's ontogenetic trajectory, then, we must take into account more widely circulating, longer timescale resources like the relations between the USA and Mexico and American attitudes toward bilingualismalthough these may be shifting locally among Marshall elementary school teachers. We must also take into account more local resources, like the more welcoming community Allie lives in and the historical moment of her arrival, when many young Mexican families' have begun settling in Marshall. These do not represent one monolithic 'macro' scale that constrains, but a heterogeneous set of resources from several scales. In our metaphor, these resources are like notes in a chord, coming together fluidly to facilitate the social identification of Allie in discrete events. Across events, many of these resources recur in more than one chord, influencing more than one event and contributing to the harmonious trajectory of her emerging identity. 
In a discrete event, like the conversation in Herná $\mathrm{n}$ and Allie's kitchen, some of these resources become relevant and facilitate the social identification occurring there. That conversation began with one of the researchers recounting the day's activities for Herná $\mathrm{n}$. When Herná $\mathrm{n}$ arrives home from work in late afternoon, his wife leaves to clean offices four nights a week. Herná $\mathrm{n}$ sat down to hear the researcher recount what his family had done that day:

1 RF: Y nos leyó un poco de su libro.

2 H: Sí. Es nuevo. Ahorita me estaba diciendo que es

3

4

5

6 H: Mmm.
And she read to us a little from her book.

Yes. It's new. She was just telling me that it's new. It's, today, today you brought it, no?

Yes, today. And, this is the new one. The new book.

The one that just came out, three days later.

Mmm.

Ever since we have known Allie, she has loved to read. Three years ago, she owned only a few books and carried around a dog-eared volume from the Diary of a Wimpy Kid series. Her parents sometimes buy her books when she asks for them, and they comment that she is always reading, but they neither praise nor condemn it.

Herná n knew that Allie's book was new because he had given her the money to purchase it, and she showed it to him immediately on his arrival. Allie emphasizes that she purchased the book only 3 days after it had become available. Allie's positive feelings about school and reading are important. They may be contributing to her rapid development as an English speaker and perhaps to her less well-developed Spanish. For example, during the conversation in her kitchen, Allie proudly announces that the book she purchased was new: '... es el nuevo, el nuevo libro. El que acaba de salir, tres días despué s' (... this is the new one. The new book. The one that just came out, three days later). In English, it makes sense to say that a book had been purchased 'just three days later, after it was published'. A Spanish-dominant speaker would likely have said, 'acaba de salir, hace tres días' (It just came out, three days ago).

Allie's somewhat awkward Spanish construction contrasts with Herná n's Spanish in this conversation. Herná n uses a typical native-Spanish speaker construction - 'trajistes' - adding the second person, informal final particle ' $\mathrm{s}$ ' to the end of a verb in the preterit. Native Spanish speakers often add this final ' $s$ ' (technically ungrammatical), aligning the conjugation in the preterit with all other tenses. Thus, you brought it today, 'hoy lo trajiste', becomes 'hoy lo trajistes'. Although Herná n's conjugation might technically be a grammatical error, it nonetheless marks him as a native speaker. This contrasts with Allie's English-like syntax, which, together with her hesitations and slower pace in Spanish, mark her as an English-dominant Spanish speaker. Because of her 
situation as a young person learning English in elementary school, she is moving away from her father's way of speaking.

As the kitchen conversation continued, one of the researchers said:

7 RF: Y ya ha leído como la mitad.

8 H: ¡¿Sí?!

9 RF: ¡Sí!

10 H: [sonido de sorpresa] ¿Ahora?

11 Yo no sé, bueno, en México no ... se

12

H: Más avanzado, no, no sé a que se deba, pero...

acostumbra mucho a leer.

RF: [se rie]

H: En México, es muy raro él que, que... ininteligible]...

It was...

H: $\quad \ldots$ se pone a leer.

A: [sigue leyendo]... aw!...

$\mathrm{H}$ : $\quad \mathrm{Y}$, este, aquí veo que ...

A $\quad \ldots$ aw!... y leen...

Por eso, me imagino que por eso es un

país más ...

Y: $\quad \mathrm{Mm}, \mathrm{mm}, \mathrm{mm}$.

A: [leyendo, ininteligible] Then, the, the, the...
A: [leyendo en voz alta en inglés,

H: ...la mayoría leen, y leen,

H: ...más avanzado. No mi vida.

Herná $\mathrm{n}$ was surprised by the fact that Allie had read so much of her book in such a short time. He then asked Allie, ¿Ahora?' ([And] now?). The question was rhetorical, but it may suggest that Herná $\mathrm{n}$ wonders what comes next for Allie. If his 9-year-old Mexican daughter eagerly anticipates the publication of an English-language book, purchases the book, and then reads half of it before 5 p.m. on a school day, what can he do to satiate her literary appetite? He may be wondering how he can supporther.
And she has already read like half of it.

Yes?!

Yes!

[tsk sound of surprise] (And) now?

I don't know, well, in Mexico... (one) is not

much accustomed to reading.

[laughs]

In Mexico, it's very unusual he/one who, who...

[reading aloud in English, unintelligible]...

It was...

... puts him/herslef to (just starts) reading.

[keeps reading] ... aw!. .

And, here, um I see that...

... aw!...

... the majority (of people) read, and read, and read...

Because of this, I imagine that, because of this, it's a

country that is more...

$\mathrm{Mm}, \mathrm{mm}, \mathrm{mm}$.

... more advanced. No my love.

[reading, unintelligible] Then, the, the, the

More advanced, no, I don't know what it's due to, but...

[reading, uninteligible]

In Mexico, it's...

[whining]

... very unusual that someone reads... 
Herná $\mathrm{n}$ then reflects on Mexicans' reading practices. In Mexico, he says, it is strange for someone to just start reading for pleasure. At that moment, Allie begins to read aloud in English from her book. As Allie is reading in English, Herná $\mathrm{n}$ describes both a person who reads and the act of reading as 'raro' (unusual). We wonder what Allie thought of this. Does she perceive Herná n's descriptions as not applying to her? Is she actively disaligning herself with this ideology of Mexican behavior? Or is she enacting a different model of Mexicanness? By using English, a code to which her father has limited access, and one that is politically and socioeconomically powerful, Allie places herself in an authoritative position with respect to her father. She (probably unintentionally) positions herself as more advanced. Allie also corrects herself as she reads in English (the ' $;$ aw!' exclamations in the transcript), a school-like behavior that her father would not have. Thus, Allie performs her father's point about the USA being more advanced than Mexico and enacts her own position as a good reader and someone more American.

Herná $\mathrm{n}$ accepts the widespread belief that the USA is more advanced than Mexico. Although Mexico is his home, he acknowledges that he could not have a financially viable life there. He believes that coming to the USA was the only way to make his desired life in Mexico possible. But this hierarchical evaluation of the countries is not all-inclusive. When asked about food, music, quality of life, friends, family, and traditions, Allie's parents strongly prefer Mexico. Allie agrees with her parents about Mexico's superiority in these respects.

As the conversation continues, Herná $\mathrm{n}$ is asked about his childhood reading practices and whether he liked school, which prompts a discussion of his experience with schooling in Mexico:

RM: ¿Cuá ndo tu eras niñ o no leíste mucho?

RF: Allie, Yessica...

H: Nnnn, no ... Casi no. Sí, este, no, casi no.

RM: Te gustaba la escuela

$\mathrm{H}: \quad$ ¿ué si me gustaba la escuela?

Y: [grita]

H: Eh ... Dáselo.

A: Ay...

$\mathrm{H}$ : Casi no. [se rie] La escuela ¿la escuela? Sí. La

escuela era bonita, pero casi no me gustaba ir a

la escuela. Sí. Yo nada más cursé hasta el grado
When you were a boy, you didn't read much?

Allie, Yessica...

Nnn, no... Almost no. Yes, that is, no, almost no.

Did you like school?

That, if I liked school?

[shreiks]

Uh... Give it to her.

Ay...

Almost no. [laughs] School school? Yes. The

school was nice. But, I mostly didn't like going to

school. Yes, I only went through the end of secondary 
de secundaria ...y...y de $\ldots$ dos añ os de

preparatoria. Nada más. Sí. Pero en sí saqué

mis papeles de preparatoria, nada más no los

cursé pero los saqué. No me gustaba, pero,

pues, sí se le [ininteligible] un poquito de ganas.

Sí, pero no, por eso le digo, casi no, no leía

libros allá. No se leen libros. Ma-,

osea, ¿los que estudian? Los que están en las

escuelas sí. Los que ya van en grados superiores,

sí, pero así como de su tamaño de ella, no.

$\mathrm{Mm}, \mathrm{mmm}$.

RF: [se rie]

H: No. Si a tanto nos ponían a leer. Y, no, sea, no, no... school... and ... and of ... two years of

high school. Nothing more. Yes. But, I did get

my high school papers, only I didn't

finish the

years, but I got my papers. I didn't like it, but,

well, I did [unintelligible] a little effort.

Yes, but no, for this, I tell you, mostly no, I didn't

read books over there. They don't read books. Bu-,

that is, those who study? Those who are in school,

yes. Those who are in higher grades,

yes, but like ones who are her size, no.

$\mathrm{Mm}, \mathrm{mmm}$.

[laughs]

No. If only they had gotten us to read that much. I, no,

that is, no, no...

Our presence as researchers facilitates Allie's parents' acceptance of some language and literacy practices, such as her English-language skills and her love of reading, but other factors constrain Allie's alignment with us. The ways in which Herná $\mathrm{n}$ talks about being Mexican may inform Allie's ongoing identification as a Mexican migrant in the USA. For instance, she may disalign with her father's model of Mexicanness because she is a reader. But she may also develop some new notion of what being Mexican means-perhaps she will see herself as a Mexican in the diaspora, as someone who can be Mexican and a reader precisely because she lives in the USA. In other words, Allie may position herself in various ways with respect to the resource that her father presupposes with his comments, the ideology about Americans reading and Mexicans not. This resource is like one note in a chord, but its role in Allie's identity remains unclear at this point in the interaction-it may be combined with other resources to form various chords or combinations of relevant resources. We do not yet know what other notes will compose the chord and what the emergent meaning of this event will be.

Although Herná $n$ mostly speaks about reading in this interaction using a generic third person (one), he makes two explicit references to his own reading practices. He says '... no leía libros allá' ( ... I didn't read books over there) and 'Si a tanto nos ponían a leer. Y, no, sea, no, no ...' (If only they had gotten us to read 
that much. I, no, that is, no, no... ). He follows this comment with, 'no se leen libros' (they don't read books), thus explaining and aligning his actions with Mexicans more generally - they don't read books in Mexico. At the end of this interaction, Herná $\mathrm{n}$ again uses the first person when he laments the fact that Mexican adults did not encourage him to read more-if only they had us read that much. If Herná $\mathrm{n}$ had grown up reading as much as Allie does, where would he be today? Would Herná $n$ have needed to come to this 'more advanced' country to make his life in Mexico viable? Perhaps he is giving his children the opportunities to read that he did not have, by buying books, by driving Allie to the Reading Olympics, by taking her to the library. Herná $\mathbf{n}$ says that he did not like school, but he never states that he did not like reading. Instead, reading stands in for advancement, for a life that he did not have. Thus, he affirms his daughter's reading.

In an analysis inspired by Latour's account of heterogeneous networks, what role do traditional analyses of speech events have? How is Herná n's interactional positioning in this event relevant to our analysis of the resources that make Allie's trajectory of identification possible? Speech events are often relevant to social identification, but their significance can be misunderstood. Occasionally, a pivotal act happens in a discrete event and thereby establishes a pattern relevant to a focal identity being analyzed. Sometimes, a type of event recurs, and this recurrence establishes a focal identity. More often, however, identities emerge across trajectories of events - at different scales in different cases, with focal identities solidifying across hours, days, months, or years (Wortham 2005). In Allie's case, we have been following her for 3 years, and her identity as a student and a reader has been emerging over that time. The speech event in Allie's kitchen was not pivotal, but it allows us to describe several heterogeneous resources that have become relevant to Allie across her several-year trajectory of learning to read.

\section{CONCLUSIONS}

To account for Allie's emerging social identifications as a student, a reader, a daughter, and a Mexican migrant, we need to determine which of various potential resources are relevant and which are not. We have likened this to finding the notes that compose a chord, as certain resources come together to facilitate events of identification, and then finding other chords that form a harmonious progression across events of identification. This metaphor is a descriptive heuristic for clarifying and addressing the problem of imagining relevant resources. Silverstein (1993) and Agha (2007) provide general accounts of how relevant context is established for social identification within and across events. Latour (2005) provides a comprehensive account of how heterogeneous resources in a network together make social identification and other processes possible. Our modest metaphor builds on insights from these general theories, helping to envision the analytic task of accounting for the emergence of social identities both within and across events. 
We illustrate this metaphor by applying it to Allie's case. In making sense of Allie's trajectory of identification as a good reader and a Mexican migrant in the NLD, relevant resources include the historical stage of Marshall's immigration trajectory (the transition from bachelors to young families, for instance), Allie's position in her own immigration trajectory and how this intersects with Marshall's, as well as more widely circulating national discourses and practices about bilingualism, literacy, education, and immigrant populations. Some of these resources will be salient for other young migrants in NLD communities and in areas of traditional Latino settlement, but the configuration of resources most salient for Allie forms a relatively distinctive network. Different cases will have somewhat different configurations of resources that account for a student's emerging identity. Analysts of discourse and social identification must avoid one-size-fits-all theories that limit relevant resources to only a few pre-established ones. We must instead do the detailed empirical work required to identify the chords or trace the networks of resources that matter in particular cases.

\section{REFERENCES}

Agha, A. 2007. Language and Social Relations. Cambridge University Press.

Agha A. and S. Wortham (eds). 2005. 'Discourse across speech-events: intertextuality and interdiscursivity in social life'. Special issue of the Journal of Linguistic Anthropology $15 / 1$.

De Fina, A. 2003. Identity in Narrative: A Study of Immigrant Discourse. John Benjamins Publishing Co.

Emerson, R., R. Fretz, and L. Shaw. 1995. Writing Ethnographic Fieldnotes. University of Chicago Press.

Gouveia, L., M. Carranza, and J. Cogua. 2005. 'The Great Plains migration' in V. Zúñ iga and R. Herná ndez-Leó n (eds): New Destinations. Russell Sage.

Hamann, E. and L. Harklau. 2010. 'Education in the New Latino Diaspora' in E. Murillo $\mathrm{Jr}$ (ed.): Handbook of Latinos and Education. Routledge.

Ká rolyi, O. 1965. Introducing Music. Penguin Books. Latour, B. 2005. Reassembling the Social. Oxford University Press.

Lemke, J. 2000. 'Across the scales of time,' Mind, Culture, and Activity 7: 273-290.

Gallo, S., H. Link, E. Allard, S. Wortham, and K. Mortimer. In press. 'Conflicting ideologies of Mexican immigrant English across levels of schooling,' International Multicultural Research Journal.
Massey, D. and M. Sá nchez. 2010. Brokered Boundaries: Creating Immigrant Identity in AntiImmigrant Times. Russell Sage Foundation.

Maxwel1, J. 1996. Qualitative Research Design: An Interactive Approach. Sage.

Millard A., J. Chapa, and C. Burillo (eds). 2004. Apple Pie and Enchiladas. University of Texas Press.

Murillo, E. Jr. 2002. 'How does it feel to be a problem? "Disciplining" the transnational subject in the American South' in S. Wortham, E. Murillo $\mathrm{Jr}$ and E. Hamann (eds): Education in the New Latino Diaspora: Policy and the Politics of Identity. Ablex Publishing.

Orellana, M. 2009. Translating Childhoods: Immigrant Youth, Language, and Culture. Rutgers University Press.

Pew Hispanic Center. 2011. 'The MexicanAmerican boom: births overtake immigration,' available at: http://pewhispanic. org/files/reports/144.pdf.

Rosa, J. 2010. 'Looking like a language, sounding like a race: making Latin@ panethnicity and managing American anxieties.' Unpublished doctoral dissertation, University of Chicago.

Ruiz, R. 1988. 'Orientations in Language Planning' in S. McKay and S. Wong (eds): Language Diversity: Problem or Resource? Heinle $\&$ Heinle.

Schoenberg, A. 1983. Structural Functions of Harmony. Faber and Faber. 
Silverstein, M. 1992. 'The indeterminacy of contextualization: when is enough enough?' in A. DiLuzio and P. Auer (eds): The Contextualization of Language. John Benjamins Publishing Co.

Silverstein, M. 1993. 'Metapragmatic discourse and metapragmatic function' in J. Lucy (ed.): Reflexive Language: Reported Speech and Metapragmatics. Cambridge University Press.

Suro, R. and A. Singer. 2002. Latino growth in metropolitan America: changing patterns, new locations. The Brookings Institution Center on Urban and Metropolitan Policy and The Pew Hispanic Center,' available at http:// www.brookings.edu/"-/media/research/files/ reports/2002/7/demographics\%20suro/ surosinger.pdf.

Talmy, L. 1985. 'Lexicalization patterns: semantic structure in lexical forms' in T. Shopen (ed.): Language Typology and Syntactic Description: Grammatical Categories and the Lexicon 3. Cambridge University Press.

U.S. Census Bureau. 2011. 'American Fact Finder: US Census 1990, Tables P001, P006, P008 and P009 (Summary Table File 1); US Census 2000, Tables P1 and P8 (Summary File 1); US Census 2010, Table P2, Hispanic or Latino and Not by
Race,' available at http://factfinder2.census. gov/.

Villenas, S. 2002. 'Reinventing Educación in New Latino Communities' in S. Wortham, E. Murillo $\mathrm{Jr}$ and E. Hamann (eds): Education in the New Latino Diaspora. Ablex.

Wortham, S. 2005. 'Socialization beyond the speech event,' Journal of Linguistic Anthropology 15: 95-112.

Wortham, S. 2006. Learning Identity. Cambridge University Press.

Wortham, S. 2012. 'Beyond macro and micro in the linguistic anthropology of education,' Anthropology \& Education Quarterly 43/2: 128-137.

Wortham, S. and C. Rhodes. 2012. 'The production of relevant scales: Social identification of migrants during rapid demographic change in one American town,' Applied Linguistics Review 3/1: 75-99.

Wortham, S., K. Mortimer, and E. Allard. 2009. 'Mexicans as model minorities in the New Latino Diaspora,' Anthropology \& Education Quarterly 40: 388-404.

Wortham S., E. Murillo Jr, and E. Hamann (eds). 2002. Education in the New Latino Diaspora. Ablex. 


\section{NOTES ON CONTRIBUTORS}

Stanton Wortham is the Judy and Howard Berkowitz Professor of Education at the University of Pennsylvania Graduate School of Education. He has written on classroom discourse and the linguistic anthropology of education, applying techniques from linguistic anthropology to uncover social positioning in apparently neutral talk. His books Acting out Participant Examples in the Classroom (1994), Linguistic Anthropology of Education (2003) and Learning Identity: The Joint Emergence of Social Identification and Academic Learning (2006), together with various articles and chapters, explore interrelations be- tween the official curriculum and covert interactional patterns in classroom discourse. His book Narratives in Action (2001) explores how storytelling can partly construct the narrator's self. Address for correspondence: Stanton Wortham, University of Pennsylvania, Graduate School of Education, 3700 Walnut Street, Philadelphia, PA 19104, USA. $<$ stantonw@gse.upenn.edu>

Catherine Rhodes is a joint Ph.D. candidate in the Education, Culture, and Society program in the Graduate School of Education and in Linguistic Anthropology in the Anthropology Department at the University of Pennsylvania. Her research interests include semiotics, language diversity and cognition, bi- and multilingualism, social identification, discursive self-making, narrative, and discourse analysis. Her dissertation research is situated in the Yucatan, Mexico and studies the relationship between the production of scientific knowledge and models of personhood. She has conducted research in Latino communities in the USA and in Mexico. <rhodesc@gse.upenn.edu> 